\title{
TRAVMA SONRASI STRES Ile TRAVMA SONRASI BÜYÜME ARASINDAKİ İLIŞKIDE SOSYAL DESTEĞİN ve MANEVIYATIN ARACI ROLÜ
}

\author{
THE MEDIATING ROLE OF PERCEIVED SOCIAL SUPPORT AND SPIRITUALITY IN \\ THE RELATIONSHIP BETWEEN POSTTRAUMATIC STRESS LEVEL AND POST- \\ TRAUMATIC GROWTH
}

\author{
Neslihan Arıcı ÖZCAN ${ }^{1}$ - Reyhan ARSLAN ${ }^{2}$
}

$\ddot{O} \mathbf{z}$

$\mathrm{Bu}$ araştırmada amaç, terör olayları karşısında yetişkin bireylerde görülen travma sonrası stres belirtileri ile travma sonrası büyüme arasındaki ilişkide, algılanan sosyal desteğin ve maneviyatın aracı rolünü incelemektir.Araştırmada veri toplamak için Olayların Etkisi Ölçeği, Çok Boyutlu Algılanan Sosyal Destek Ölçeği, Manevi Yönelim Ölçeği, Travma Sonrası Büyüme Ölçeği kullanılmıştır. Araştırmanın çalışma grubu İstanbul ilinde yaşayan yaş ortalaması 23,57 olan $(S S=7,95) 723$ bireyden (473 kadın, 250 erkek) oluşmaktadır. Çalışmada terör olayları karşısında yetişkin bireylerde görülen travma sonrası stres belirtileri ile travma sonrası büyüme arasındaki ilişkide algılanan sosyal desteğin ve maneviyatın aracı rolü Seri Çoklu Aracılık Modeli kullanılarak test edilmiştir. Araştırma sonucunda, travma sonrası stres düzeyi yüksek grupta, travmatik stres düzeyi ve travma sonrası büyüme arasındaki ilişkide algılanan sosyal destek ve manevi yönelimin aracıllk ettiği, tüm modelin anlamlı olduğu $\left(F(3,342)=53.71, p<.001, R^{2}=.32\right)$ ve toplam varyansın \%32'sini açıkladığı görülmüşșïr. Bulgular ilgili alanyazı doğrultusunda tartışılmış ve çeşitli öneriler sunulmuştur.

Anahtar Kelimeler: Terör olayları, Travma Sonrası Stres, Travma Sonrası Büyüme, Sosyal Destek, Maneviyat

\begin{abstract}
The aim of this study is to investigate the mediating role of perceived social support and spirituality in the relationship between posttraumatic stress level and posttraumatic growth in adult individuals in the face of terrorist events. In the research, the Impact of Event Scale-Revised, Multi-Dimensional Perceived Social Support Scale, Post Traumatic Growth Scale and Spiritual Orientation Scale were used. The study group consisted of 723 individuals (473 women, 250 men) with a mean age of $23.57(S D=7.95)$ living in Istanbul. In this study, the mediating role of perceived social support and spirituality in the relationship between posttraumatic stress level and posttraumatic growth in adult individuals in the face of terrorist events were tested using the Serial Multiple Mediator Model. In the post-traumatic stress-high group, the relationship between traumatic stress level and post-traumatic growth is mediated by perceived social support and spiritual orientation and the whole model is significant $\left(F(3,342)=53.71, p<.001, R^{2}=.32\right)$ and $32 \%$ of the total variance was explained. The findings were discussed in accordance with the related literature and recommendations were made to the related parties.
\end{abstract}

Keywords: Terrorist Events, Post-Traumatic Stress, Post-Traumatic Growth, Social Support, Spirituality.

\footnotetext{
1 Dr. Öğr. Üyesi, İstanbul Medeniyet Üniversitesi, Sosyal Hizmet Bölümü, neslhan.ozcan@medeniyet.edu.tr, Orchid: 0000-0002-6169-1445.

${ }^{2}$ Arş. Gör., İstanbul Medipol Üniversitesi, Rehberlik ve Psikolojik Danışmanlık Bölümü, reyhanarslan@medipol.edu.tr, Orchid, 0000-0001-9344-2059.
} 


\section{GİRIŞ}

“Öldürmeyen güç beni daha güçlü yapar” Nietzsche (akt. Bataille, 2000).

Günümüzde terör olaylarının dünyanın her yerinde arttığı söylenebilir. Terör kelimesi, Latince "terrere" sözcügünden türetilmiştir ve "büyük korku, dehşet" anlamlarında kullanılmaktadır. Terör olaylarının tanımı; terörün nedenlerinin çeşitliliğinden, farklı hukuki yapılanmalardan, farklı tehdit algılarından ve teröristlerin farklı 1rk, din, politika ve ideolojik yapılarından tanımlanması zordur (Dedeoğlu, 2003). Terör olaylarında insana ve insanlığa yapılan uygulamalar fiziksel sonuçtan çok daha çok psikolojik ve sosyolojik etkilere sahiptir (Gökler ve Y1lmaz, 2001). Bu etkiler arasında bireysel ve toplumsal algılarının ve yapıların olumuz yönde değişmesi (Şavur ve Tomas, 2010), ekonomik düzeninin ve sosyal düzeninin zarar görmesi (Burgoon, 2006; Fred, 2001) yer almaktadır. Bütün bu etkiler ile beraber terör olayları dünyada bireyler üzerinde en yüksek psikolojik etkiye neden olabilecek şekilde tasarlanmıştır (Everly ve Mitchell 2001). Literatürde terör olaylarına doğrudan maruz kalmış kişilerde patolojik bir tepki, özellikle de travma sonrası stres bozukluğu belirtilerinin görüldüğü ifade edilmiştir (Galea ve Resnick 2005; Hobfoll, Canetti, Johnson, 2006; Norris, Friedman, Watson, 2002; Shalev, Tuval, Frenkiel-Fishman, Hadar ve Eth, 2006).

Travma sonrası stres bozukluğu gerçek bir ölüm veya ölüm tehdidinin bulunduğu, bireyin kendisinin yaşadığı ya da şahit olduğu bir ağır yaralanmanın veya fiziksel bütünlüğe yönelik bir tehdidin sonucunda oluşan, bireyde temel olarak yoğun kaygı duygusu yaşatan ve bireyin işlevini ciddi anlamda bozan bir bozukluk olarak dile getirilmektedir (Bleich, Gelkopf ve Solomon, 2003; Galea ve ark., 2002; Hobfoll ve ark., 2006). Özellikle terör olayları bireyin ve çevresinin fiziksel bütünlügünü tehdit eden ve bireyde yoğun kaygı ve işlev kaybı yaşatabilen travmatik olaylardır (Hobfoll, Canetti-Nisim, Johnson, Palmieri, Varley ve Galea, 2008). Bu travmatik olaylar dünya da görüldügü gibi Türkiye'de de görülmektedir ve bireyler bu durumdan psikolojik etkilenebilmektedir (Yıldırım ve Aker 2009; Güloğlu ve Irmak, 2013; Şavur ve Tomas 2010). Janoff-Bulman'un (1992) öne sürdüğü sosyal bilişsel teoriye göre bireyin travma sonrasında yaşadığı olayı anlamlandırmak ve yaşamını anlamlandırmak için yoğun ruminatif düşünceleri ve bilişsel süreçleri olmakta ve kendi ile ilgili (kendine verdiği değer) ve dünya ile ilgili (dünyanın hayırseverliği, dünyanın anlamlılığı) temel görüşleri sarsılmaktadır. Bu temel varsayımlar (dünyanın hayırseverliği, dünyanın anlamlılığı ve kişinin kendine verdiği değer) sarsıldığında bireyin travma sonrası stres bozukluğu sorunu yaşama ihtimali artabilmektedir. Şayet bu varsayımlar sarsılmadıysa, bireyde travma sonrası büyüme görülebilmektedir.

Travma sonrası büyüme, bireyin zorlu yaşam deneyimi ile çabalarken olumlu psikolojik değişimi deneyimlemesidir (Tedeschi ve Calhoun 2004, s.1). Travma sonrası büyümenin travma sonrası stres belirtileri gösteren bireylerde görüldüğü birçok çalışmada ifade edilmektedir (Butler ve ark., 2005; Dekel ve Hobfoll 2007; Helgeson, Reynolds ve Tomich, 2006; Laufer ve Solomon, 2006). Ayrıca terörle ilgili travma sonrası büyüme çalışmalarında (Bleich ve ark. 2003, Butler ve ark., 2005), travma sonrası büyümenin özellikle orta düzeyde travma sonrası stres belirtileri gösteren bireylerde daha çok ortaya çıktığı vurgulanmıştır.

Janoff-Bulman (2006), travma sonrası büyümenin üç süreci olduğunu belirtmiştir. Bunlar acı çekme yoluyla güç, varoluşsal yeniden değerlendirme ve psikolojik hazırlıktır. Bütün bu süreçler de bireyin kendilik algısında, ilişkilerinde ve yaşam felsefesinde değişikliklere yol açabilmektedir. Bireyin kendilik algısındaki değişmelere bireyin bilişsel süreçleri, endişesi, hayatta kalmayı sağlayan kişisel eğilimleri etki ederken, bireyin ilişkilerindeki değişikliklerinde ise bireyin çevresinin olay sonrasında verdiği sosyal desteğin, bireyin olaya verdiği tepkinin, bireyin sosyal destek arama davranışının ve olayın olduğu sosyal bağlamın etki 
ettiği ifade edilmektedir. Bireyin yaşam felsefesindeki değişikliklerde de bireyin maneviyatı, yaşamdaki önceliklerini belirlemesi ve yaşamın biricikliğini anlaması yer almaktadır (Calhoun ve Tedeschi, 2006; Calhoun, Cann ve Tedeschi, 2010).

Hem sosyal desteğin (Prati ve Pietrantoni, 2009) hem maneviyatın (Calhoun, Cann, Tedeschi ve McMillan, 2000; Shaw, Joseph ve Linley, 2005) travma sonrası büyümede anahtar bir rol oynadığını ifade eden birçok çalışma bulunmaktadır. Sosyal desteğin travma sonrası büyümedeki etkisinde bireyin sosyal destek araması ve bireyin çevresinde sosyal destek verecek kişilerin olması yer almaktadır ve her ikisi bireyin sosyal kaynaklarını geliştirmekte ve bireyde oluşabilecek yalnızlık hissini azaltmaktadır (Cryder, Kilmer, Tedeschi, ve Calhoun, 2006; Maguen, Vogt, King, King ve Litz, 2006; Tedeschi ve Calhoun, 2004). Buna ilaveten, destekleyici sosyal bir çevre bireyin olay hakkında geri bildirim almasını sağlayabilmekte ve bireyin zorlayıcı olayla başa çıkmasını kolaylaştırabilmektedir. Bu destekleyici sosyal çevre devam ettikçe birey, kendini bulunduğu ortama ve bireylere karşı güvende hissedebilmekte ve hatta çevresine empatik davranabilmektedir (Cryder ve ark. 2006; Tedeschi ve Calhoun 2004). Maneviyatın travma sonrası büyümedeki etkisinde ise bireyin dini inançları, yaptığı dini ritüeller (Pargament, Koenig ve Perez, 2000), dua etmesi/meditasyon yapması (Tedeschi ve Calhoun 2004), bilgeliğin gelişimi (Linley, 2003) ve yüce bir varlıkla iletişimin artması (Tedeschi ve Calhoun 1995; Woodcock 2001) yer almaktadır.

Kaynak tutumu modeli (Conservation of Resources/COR), terör olayları sonrasında bireyin travma sonrası stres mi yoksa travma sonrası büyüme mi yaşayacağını açıklayan bir modeldir (Benight, Freyaldenhoven, Hughes, Ruiz, Zoschke ve Lovallo, 2000; Ironson ve ark. 1997). Terör olayı, bireyin maddesel (ulaşım, ev, barınma, ekonomik güç) ve psikolojik (kendini yeterli hissetme, sosyal destek alacak kişilerin vefatı) kaynaklarının kaybının en fazla olduğu travmatik olaylardır (Hobfoll, 2008). Bu kayıpların olumsuz etkisini yok edecek kaynakların olması bireyin travma sonrası stres yerine travma sonrası büyüme yaşayacağının bir göstergesi olabilir. Bu bağlamda, terörle ilgili travmatik yaşantılarda hem sosyal desteğin (Hall ve ark. 2008; Maguen ve ark. 2006; Rime', 2009) hem de maneviyatın travma sonras1 büyümede etkili olduğunu söyleyen çeşitli çalışmalar (Calhoun ve ark. 2000; Laufer ve Solomon, 2006; Milam ve ark. 2005) mevcuttur.

Türkiye'de yaşayan bireyler de diğer ülkelerde yaşayan bireyler gibi yakın zamanda çeşitli terör saldırılarına doğrudan veya dolaylı yollarla maruz kalmışlardır. Ancak bu terör saldırılarının yetişkin bireyleri nasıl etkilediğini ele alan çalışmalar çok kısıtlı sayıdadır (Duran ve Ünsal, 2014; Eşsizoğlu, Yaşan, Bülbül, Önal, Akgün-Yıldırım, ve Aker 2009; Güloğlu ve Irmak, 2013; Şavur ve Tomas 2010; Aker ve ark., 2008). Travma sonrası büyüme ile ilgili de ulusal alanyazında az sayıda çalışmaya (Karaman ve Tarım 2018; Kardaş ve Tanhan, 2018) rastlanmıştır. Ancak terör olayları sonrasında travma sonrası stresi ve travma sonrası büyümeyi birlikte ele alan herhangi bir çalışmaya rastlanmamıştır. Oysaki bu konuda yapılacak bir çalışma yaşanılacak herhangi bir terör olayı ve travmatik bir yaşantı karşısında travma konusundaki çalışan uzmanların özellikle hangi tür kaynakları kullanarak önleyici, geliştirici ve müdahale edici programlar geliştirmesine yol açabilir. Ayrıca travmatik olay yaşayan bireylerin yaşadıkları travmayı travma sonrası büyümeye dönüştürebilmeleri için hangi tür kaynakları (sosyal destek ve maneviyat) kullanmalarının yararlı olacağını göstermiş olabilir. Buradan hareketle, bu çalışmanın amacı terör olayları karşısında yetişkin bireylerde görülen travma sonrası stres belirtileri ile travma sonrası büyüme arasındaki ilişkide algılanan sosyal desteğin ve maneviyatın aracı rolünü incelemektir.

Yukarıda belirtilen amaç doğrultusunda araştırmanın denenceleri şu şekildedir.

$\mathrm{H}_{1}$ : Travma sonrası stres düzeyi yüksek olan grupta travma sonrası stres düzeyi ile travma sonrası büyüme arasında bir ilişki vardır. 
$\mathrm{H}_{2}$ : Travma sonrası stres düzeyi yüksek olan grupta travma sonrası stres düzeyi ile sosyal destek arasında bir ilişki vardır.

$\mathrm{H}_{3}$ : Travma sonrası stres düzeyi yüksek olan grupta travma sonrası stres düzeyi ile manevi yönelim düzeyi arasında bir ilişki vardır.

$\mathrm{H}_{4}$ : Travma sonrası stres düzeyi yüksek olan grupta sosyal destek düzeyi ile travma sonras1 büyüme arasında bir ilişki vardır.

$\mathrm{H}_{5}$ : Travma sonrası stres düzeyi yüksek olan grupta manevi yönelim düzeyi ile travma sonrası büyüme arasında bir ilişki vardır.

$\mathrm{H}_{6}$ : Travma sonrası stres düzeyi yüksek olan grupta sosyal destek düzeyinin travma sonrası stres düzeyi ile travma sonrası büyüme düzeyi arasındaki ilişside aracı rolü vardır.

$\mathrm{H}_{7}$ : Travma sonrası stres düzeyi yüksek olan grupta manevi yönelim düzeyinin travma sonrası stres düzeyi ile travma sonrası büyüme arasındaki ilişkide aracı rolü vardır.

\section{YÖNTEM}

\subsection{Araştırma Modeli}

Araştırma ilişkisel tarama modeli kullanılarak yapılan betimsel nitelikte bir çalışmadır. İlişskisel tarama modeli, iki ve daha çok sayıdaki değişken arasında birlikte değişimin varlığını ve/veya derecesini belirlemeyi amaçlayan araştırma modelidir (Karasar, 2012).

\subsection{Katılımcılar}

Araştırmanın verileri İstanbul Medipol Üniversitesi İnsan ve Toplum Bilimleri Fakültesinde ve Eğitim Fakültesinde okuyan öğrenciler ve onların yetişkin yakınlarından 2017 yıl1nın Mart ve Nisan ayları arasında kartopu örnekleme yöntemi ile toplanmıştır. 743 yetişkin katılımcının yaşları 18-72 $\left(\mathrm{X}_{\text {ort }}=23.74, S S=7.96\right)$ aralığında değişmektedir. Çalışma grubunun \%65.1'ini kadın $(N=484), \% 34.9$ 'unu erkek $(N=259)$ bireyler oluşturmaktadır. Katılımc1ların travmatik olayları deneyimleme sıklığına bakıldığında, çoğunluğunun (\%65.8) bu olaylara yaşamlarında bir kez maruz kaldığı anlaşılmıştır. Katılımcılar, "Türkiye'deki terör olaylar1", "İşid'in Suriye ve diğer ülkelerdeki eylemleri", "Reina patlaması", "Ankara patlaması", "Atatürk Havalimanı patlaması", "Paristeki patlama" gibi travmatik olarak yaşantıladıkları çok çeşitli olaylar ifade etmişlerdir. Katılımcıların maruz kaldıkları travmatik olayları ne şekilde değerlendirdiği incelendiğinde, \%16.3'ünün $(N=121)$ bu olayları kendi varlığına yönelik bir tehdit olarak algıladığı ("Taksimdeki patlama benim oraya gidişimden tam bir gün sonra gerçekleşti”, “Tankın namlusunu bana çevirmesi” vb.), \%4.4'ünün $(N=33)$ aile ve yakınlarının varlığına yönelik tehdit olarak algıladığı ("Komşularımın olay yerinde bulunması", "Bir arkadaşım patlama sırasında Beşiktaş'taydı. Haber alamayınca çok endişelendim." vb.), \%16.6'sının $(N=123)$ devlete yönelik tehdit olarak algıladığı ("Babam turizm sektöründe çalıştı̆ğ için ülkemizde turizmin zarar gördüğünü ve daha kötüye gideceğini bilmek", "devletin güçsüz kalması" vb.), \%40.8'inin $(N=303)$ diğer insanların varlığına yönelik tehdit olarak algıladı̆̆ı ("masum insanların ölmesi”, "insanların zarar görmesi”, "insanlara yapılan eziyetler” vb.), \%7.4'ünün ise yaşadıkları travmatik olayları olumlu yönde algıladığı ("Ülkemizin birlik olduğunu gördükten sonra çok mutlu oldum.") görülmüştür.

Katılımcılara ait demografik bilgiler Tablo 1'de gösterilmiştir. 
Tablo 1. Katılımcılara Ait Demografik Bilgiler

\begin{tabular}{llll}
\hline & & f & $\%$ \\
\hline Cinsiyet & Kadın & 484 & 65.1 \\
& Erkek & 259 & 34.9 \\
& Toplam & 743 & 100 \\
\hline Travmatik olayları deneyimleme sıklığı & $1 \mathrm{kez}$ & 489 & 65.8 \\
& $2 \mathrm{kez}$ & 174 & 23.4 \\
& $3 \mathrm{kez}$ ve üzeri & 80 & 10.8 \\
& Toplam & 743 & 100 \\
\hline Terör olaylarına yönelik tehdit algısı & Bireysel tehdit & 121 & 16.3 \\
& Aile/yakınlara yönelik tehdit & 33 & 4.4 \\
& Devlete yönelik tehdit & 123 & 16.6 \\
& Diğer insanlara yönelik tehdit & 303 & 40.8 \\
& Tümü & 41 & 5.5 \\
& Etkilemedi & 1 & .1 \\
& Olumlu alg1 & 55 & 7.4 \\
& Belirtmemiş & 66 & 8.9 \\
& Toplam & 743 & 100 \\
\hline
\end{tabular}

\section{3. Ölçme Araçları}

\section{Olay Etkisi Ölçeği}

Horowitz ve arkadaşları tarafindan (1979) geliştirilen, sonra DSM-IV travma sonrası stres bozukluğu ölçütlerine göre Weiss ve Marmar (1997) tarafından tekrar gözden geçirilen ve Türkçe'ye Çorapçıoğlu ve arkadaşları (2006) tarafından uyarlanan, travma sonrası stres düzeyini ölçen bir öz bildirim ölçeğidir. 22 maddelik 5'li Likert tipi ölçeğin üç alt boyutu bulunmaktadır. Bu alt boyutlar; yeniden yaşama, kaçınma ve aşırı uyarılmadır. Ölçeğin ve alt ölçeklerinin CAPS (Clinician Administred Post Traumatic Stress Disorder Scale) ölçeği ve alt ölçekleri ile korelasyonu Spearman analizi ile ele alınmış ve yapılan değerlendirme sonucunda toplam puanın $(r=.70)$, Yeniden Yaşama puanının ( $r=.69)$ ve Aşırı Uyarılmışlık puanının $(r=.63)$ korelasyonlarının iyi düzeyde olduğu saptanmıştır $(p<0.001)$. Kaçınma puanının korelasyon katsayısı, istatistiksel olarak anlamlı düzeyde olsa bile orta derecede bulunmuştur $(r=.49)$. Kesim değerinin ise 24 ile 33 arasında olduğu durumlarda duyarlılık ve özgüllük değerlerinin her ikisinin de \%70’ten yüksek olduğu görülmüştür. Ölçeğin iç tutarlık katsayısı tüm grup için $r=.94$ bulunmuştur. Bu araştırmada ise ölçeğin iç tutarlık katsayısı tüm grup için $r=.93$ olarak bulunmuştur.

Çok Boyutlu Algllanan Sosyal Destek Ölçeği (Multidimensional Scale of Perceived Social Support-MSPSS

Zimet ve arkadaşları tarafından (1988) geliştirilen ve Eker ve arkadaşları tarafından (2001) Türkçe'ye uyarlanan ölçek, üç farklı kaynaktan alınan sosyal desteğin yeterliliğini ölçen 12 maddelik, 7'li Likert tipi bir öz bildirim ölçeğidir. Ölçekte, üç farklı kaynaktan al1nan sosyal destek; aile (örneğin, annem, babam, eşim, çocuklarım, kardeşlerim), arkadaş, aile ve arkadaşlar dışında olan bir insan (örneğin, flört, nişanlı sözlü, akraba, komşu, doktor) olarak tanımlanmıştır. Ölçeğin tamamından alınabilecek en düşük puan 12, en yüksek puan 84 'tür. Elde edilen puanın yüksek olması algılanan sosyal desteğin yüksek olduğunu göstermektedir. Ölçeğin geçerlik ve güvenirlik bilgileri üç farklı gruptan (yatarak tedavi gören psikiyatri hastalarının oluşturduğu psikiyatri grubu, cerrahi müdahale yapılan hastaların oluştur- 
duğu cerrahi grubu ve rastgele seçilmiş hasta ziyaretçilerinin oluşturduğu hasta olmayan grup) sağlanmıştır. Ölçeğin iç tutarlığı, hem toplam puan hem de alt ölçekler için üç grupta .80 ile .10 arasında değişen değerlerdedir ve kabul edilebilir bir iç tutarlılıktır. Üç grup birleştirilerek elde edilen faktör analizi sonucuna göre ise orijinal ölçeğe uygun olarak toplam varyansın \% 75'ini açıklayan üç faktör elde edilmiştir. Yapı geçerlilik çalışmalarında, ölçeğin Algılanan Sosyal Destek Ölçeği ile pozitif yönde ilişkili olduğu bulunmuştur. Ayrıca psikiyatri örnekleminde umutsuzluk, yalnızlık ölçekleri ve belirti tarama listesi ile negatif yönde anlamlı bir ilişki bulunmuştur. Benzer şekilde, cerrahi ve normal örneklemde de yalnızlık ölçeği ile arasında negatif yönde bir ilişki bulunmuştur. Buradan hareketle, ölçek geçerli ve güvenilir bir araç olduğu söylenebilir. Bu araştırmada ise ölçeğin iç-tutarlık katsayısı tüm grup için $r=.91$ olarak bulunmuștur.

\section{Manevi Yönelim Ölçeği}

Kasapoğlu (2015) tarafından geliştirilen ölçek, manevi yönelimi ölçen 16 maddelik, 7'li Likert tipi bir öz bildirim ölçeğidir. Tek boyutlu olan ölçekte en düşük 16, en yüksek 112 puan alınmaktadır. Puan artışı manevi yönelimin yüksek düzeyde olduğunu göstermektedir. Ölçeğin yapı geçerliğini sınamak için açımlayıcı ve doğrulayıcı faktör analizi yapılmıştır. Ölçeğin toplam varyansın \%47,50'sini açıklayan bir faktörden oluşan ve uyum endekslerine uygun bir ölçek $(\chi 2=239.718, \mathrm{sd}=100, \mathrm{p}=.000), \chi 2 / \mathrm{sd}=2.39, \mathrm{RMSEA}=0.06, \mathrm{RMR}=0.05$, GFI=0.93, AGFI=0.90, CFI=0.95, IFI=0.95, NFI=0.92) olduğu tespit edilmiştir. Ölçeğin Cronbach Alfa iç tutarlılık katsayısı .87'dir. Ölçeğin test-tekrar test güvenirlik katsayısı $r=.84$ 'tür. Bu çalışmada ise ölçeğin iç-tutarlık katsayısı tüm grup için $r=.97$ olarak bulunmuştur.

\section{Travma Sonrası Büyüme Ölçeği (Posttraumatic Growth Inventory, PTGI)}

Tedeschi ve Calhoun (1996) tarafından geliştirilen ve Dürü (2006) tarafindan Türkçe'ye uyarlanan ölçek travmatik yaşantı sonrası büyümeyi ölçen, 21 maddelik 6'lı Likert tipi (0-5) bir öz bildirim ölçeğidir. Ölçekte en düşük puan 0 ve en yüksek puan $105^{\prime}$ tir. Artan puanlar, bireyin travmatik yaşantı karşısında büyüme düzeyinin arttığını göstermektedir. Ölçeğin orijinalinde (Tedeschi ve Calhoun 1996), Cronbach Alfa iç tutarlılık katsayısının .90 olduğu belirtilmektedir. Alt ölçeklerin iç tutarlılığı ise .66 ile .85 arasında değişmektedir. Test-tekrar test güvenirliği için yapılan çalışmada $r=.71$ olarak bulunmuştur. Ayrıca orijinal ölçeğin iyimserlik, dinsel katılım, dışadönüklük, deneyimlere açıklık, uyumluluk ve vicdanlılık gibi değişkenlerle pozitif yönde anlamlı ilişkisi olduğu ifade edilmiştir. Geçerlik çalışması için yapılan faktör analizinde ise orijinal ölçeğin beş alt boyutu olduğu (başkalarıyla ilişkiler, yeni firsatlar, kişisel güçlülük, manevi değişim ve yaşamı takdir etme) tespit edilmiştir.

Türkçe'ye uyarlanan ölçeğin ise Cronbach Alfa iç tutarlılık katsayıs1 .93 olarak hesaplanmıştır. Çalışmada, ölçeğin yapı geçerliğine Temel Eksenler Faktörlemesi ve Varimax rotasyonu ile bakılmış ve beş faktörlü bu çözümde varyansın \%67.84'ünün açıklanabildiği belirtilmiştir. Bu bulgular 1şığında, Travma Sonrası Büyüme Ölçeği’nin kabul edilebilir düzeyde geçerli ve güvenilir bir ölçüm aracı olduğu belirtilmiştir. Bu çalışmada ise ölçeğin iç tutarlılık katsayısı tüm grup için $r=.92$ olarak bulunmuştur.

\section{Kişisel Bilgi Formu}

Araştırmacılar tarafından geliştirilen kişisel bilgi formunda demografik değişkenlere ait sorular (yaş, cinsiyet, medeni durum, eğitim durumu, maddi durum), olay değişkenlerine ait sorular (olay/olayların kendisi, olayın türü, olayın sıklığı, deneyimleme/maruz kalma şekli) ve bireysel etkilere (en çok etkileyen durum, etkilenme şiddeti, başa çıkma şekli, destek alıp almaması) ait sorular yer almaktadır.

\section{4. İşlem}


Araştırmanın yürütülebilmesi için üniversite etik kurulundan gerekli izinler alındıktan sonra, katılımcılar araştırmaya davet edilmiş ve araştırma hakkında bilgilendirildikten sonra, çalışmaya gönüllü olarak katıldıklarına dair sözlü ve yazılı onamları alınmıştır. Kendisi ile ilgili her türlü kişisel bilginin gizli kalacağı katılımcılara aktarılmış ve istediği zaman çalışmayı bırakabileceği bildirilmiştir. Anketler kâğıt-kalem formatında dağıtılmış olup tümünün doldurulması yaklaşık 15 dakika sürmüştür.

\section{5. İstatiksel Analiz}

Bu çalışmada istatistiksel analizlerden önce, bilgilerin doğruluğu ve eksik değerler için veriler incelenmiş ve daha sonra, \pm 3.29 'u aşan z puanlarına göre tespit edilen aykırı değerler verilerden çıkarılmıştır. Bundan sonra normal veri dağılımı test edilmiş ve normallik sağlanmıştır (Tabachnick ve Fidell, 2006). Çalışmanın değişkenleri arasındaki ilişkileri analiz etmek için Sosyal Bilimler için İstatistik Paketi (SPSS) versiyon 23 kullanılmıştır. Değişkenler arasındaki ilişkileri saptamak için SPSS 20 paket programı kullanılarak korelasyon analizi yapılmıştır. Arabuluculuk etkisini test etmek için SPSS'nin PROCESS makrosu tarafindan Seri Çoklu Arabuluculuk Analizi yapılmıştır (Hayes, 2013).

\section{BULGULAR}

\section{1. Korelasyon analizi}

Analizlere geçmeden önce, çalışma grubu, Olay Etkisi Ölçeği kullanılarak elde edilen travma puanının ortalaması hesaplanarak ikiye bölünmüştür. Buna göre, çalışma grubundan elde edilen travma puanı ortalamasının üstünde kalan kişiler "travma puanı yüksek grup", ortalamanın altında kalan kişiler ise "travma puanı düşük grup" olarak değerlendirilerek ayrılmış ve analizler bu iki grup için ayrı yürütülmüştür. Değişkenler arasındaki korelasyon katsayıları Tablo 2'de gösterilmiştir. .

Olay Etkisi Ölçeği ile elde edilen travma puanları yüksek olan grupta, travmatik olaylar karşısında yaşanan stres düzeyi ile algılanan sosyal destek ve travma sonrası büyüme pozitif yönde ilişkili bulunmuştur (sırasıyla, $r=.12, p<.05 ; r=.26, p<.01$ ). Bunun yanı sıra, bu grupta travmatik stres düzeyi ile manevi yönelim arasında anlamlı bir ilişki saptanmamıştır $(r=.03, p=.53)$. Öte yandan, travma puanları düşük olan grupta, travmatik olaylar karşısında yaşanan stres düzeyi ile manevi yönelim negatif yönde ilişkiliyken $(r=-.14, p<.01)$; travmatik stres düzeyi ile algılanan sosyal destek arasında herhangi bir ilişki saptanmamıştır $(r=-.05 ; p=.37) . \mathrm{Bu}$ grupta, travmatik stres düzeyi ile travma sonrası büyüme ise pozitif yönde ilişkili bulunmuştur $(r=.23, p<.01)$.

Tablo 1. Değişkenler Arasındaki Pearson Korelasyon Katsayıları

\begin{tabular}{|c|c|c|c|c|c|c|}
\hline \multicolumn{7}{|c|}{ Korelasyon Katsayıları } \\
\hline Değişkenler & $\mathrm{M}$ & SS & 1 & 2 & 3 & 4 \\
\hline Travma puanı yüksek grup $(\mathrm{N}=346)$ & 49.24 & 10.93 & 1 & & & \\
\hline 1. Olay Etkisi & & & & & & \\
\hline 2. Alg1lanan Sosyal Destek & 60.09 & 14.85 & $.12 *$ & 1 & & \\
\hline 3. Manevi Yönelim & 87.06 & 19.55 & .03 & $.47 * *$ & 1 & \\
\hline 4. Travma Sonrası Büyüme & 67.74 & 15.69 & $.26^{* *}$ & $.50 * *$ & $.39 * *$ & 1 \\
\hline Travma puanı düşük grup $(\mathrm{N}=377)$ & 33.28 & 16.94 & 1 & & & \\
\hline 1. Olay Etkisi & & & & & & \\
\hline 2. Alg1lanan Sosyal Destek & 60.09 & 18.39 & -.05 & 1 & & \\
\hline 3. Manevi Yönelim & 88.82 & 22.95 & $-.14 * *$ & $.30 * *$ & 1 & \\
\hline 4. Travma Sonrası Büyüme & 62.35 & 21.81 & $.23^{* *}$ & $.30 * *$ & $.25 * *$ & 1 \\
\hline
\end{tabular}

$* p<.05, * * p<.01$ 


\subsection{Seri Aracı Değişken Analizi}

Olay etkisi (travmatik stres düzeyi) ve travma sonrası büyüme arasındaki ilişkide algılanan sosyal destek ve manevi yönelimin aracı rolünün belirlenmesinde Hayes (2009) tarafından önerilen Seri Çoklu Aracılık Modeli (Serial Multiple Mediator Model) kullanılmıştır. İki aracı değişkenin olduğu bu model üç dolaylı etki ve bir doğrudan etki içermektedir. Şekil 1'de görüldüğ̈̈ gibi bu etkiler şöyledir; algılanan sosyal destek aracılığıyla travmatik stres düzeyinin travma sonrası büyüme üzerindeki dolaylı etkisi $\left(a_{1} b_{1}\right)$, manevi yönelim aracıllı̆ııla travmatik stres düzeyinin travma sonrası büyüme üzerindeki dolaylı etkisi $\left(\mathrm{a}_{2} \mathrm{~b}_{2}\right)$, algılanan sosyal destek ve manevi yönelimin seri aracılığıyla travmatik stres düzeyinin travma sonrası büyüme üzerindeki dolaylı etkisidir $\left(\mathrm{a}_{1} \mathrm{~d}_{1} \mathrm{~b}_{2}\right)$. Bu üç dolaylı etkinin toplamı, travmatik stres düzeyinin toplam dolaylı etkisini gösterir $\left(X: a_{1} b_{1}+a_{2} b_{2}+a_{1} d_{1} b_{2}\right)$. Toplam dolaylı etkilere travmatik stres düzeyinin travma sonrası büyümeye doğrudan etkisi eklendiğinde bu ifade olay etkisinin toplam etkisini göstermektedir (c).

$$
c=c^{\prime}+a_{1} b_{1}+a_{2} b_{2}+a_{1} d_{1} b_{2}
$$

Seri çoklu aracılık modelinde travmatik stres düzeyinin travma sonrası büyüme üzerindeki toplam dolaylı etkisi, travmatik stres düzeyinin travma sonrası büyümeye toplam etkisiyle (c), travmatik stres düzeyinin travma sonrası büyüme üzerindeki doğrudan etkisi (c') arasındaki farka eşittir.

$$
c-c^{\prime}=a_{1} b_{1}+a_{2} b_{2}+a_{1} d_{1} b_{2}
$$

$\mathrm{Bu}$ çalışmada seri çoklu aracılık modeli, travma puanı yüksek ve düşük grup için ayrı test edilmiştir. Mevcut çalışmada seri çoklu aracılık modeli üç farklı dolaylı etki içermektedir. Dolaylı etkileri incelemek amaciyla SPSS programı üzerinden PROCESS eklentisi kullanılmıştır. Yapılan analizlerde, 10000 bootstrap örneklemesi kullanılmış ve tahminler, yanlılık hatasından arındırılmış ve düzeltilmiş sonuçları yansıtan \%95 güven aralığında değerlendirilmiştir. Dolaylı aracılık etkilerini açıklayabilmek için ind1, ind2 ve ind3 ifadeleri kullanılmıştir.

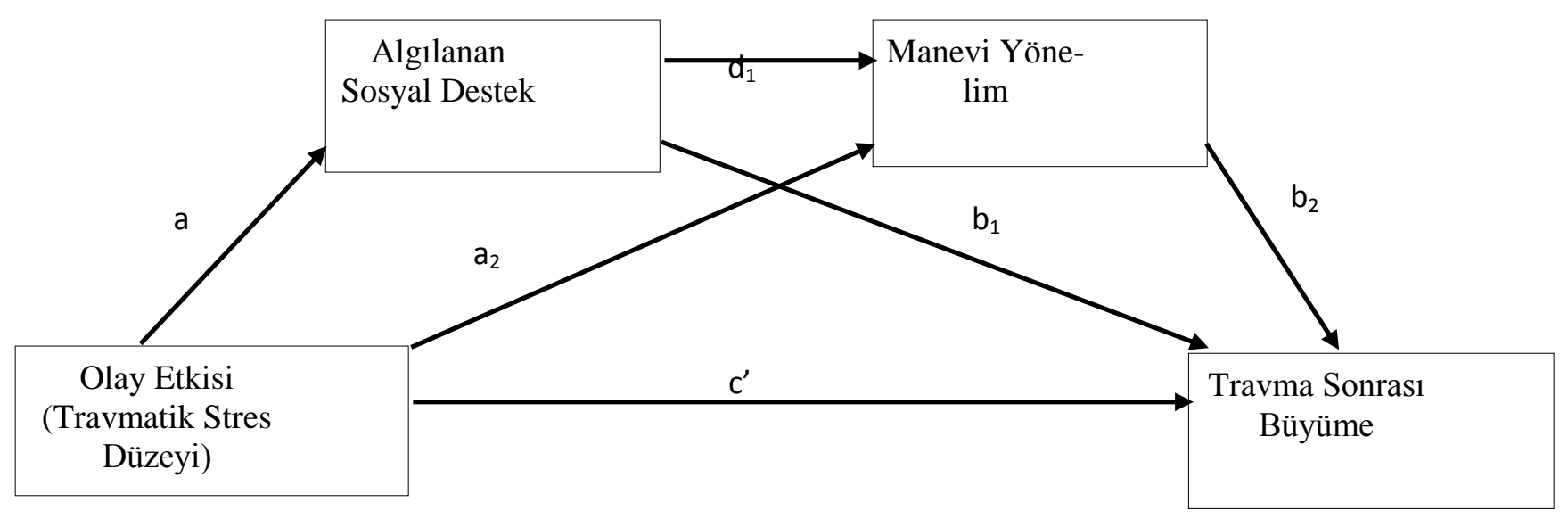

Şekil 1. Seri Çoklu Aracılık Modeli 


\section{Travma Puanı Yüksek Grupta Seri Aracı Değişken Analizi}

Travmatik stres düzeyi yüksek olan grupta yapılan seri çoklu aracı değişken analizine göre, bu grupta travmatik stres düzeyinin travma sonrası büyüme üzerindeki toplam etkisi anlamlıdır ( $c$ yolu; $\beta=.37, S H=.08, t=4.98, p<.01$, CI $[.23, .52]$ ). Öte yandan aracı değişkenler (algılanan sosyal destek ve manevi yönelim) denkleme eş zamanlı alındığında travmatik stres düzeyi ile travma sonrası büyüme arasındaki doğrudan ilişki azalmış; ancak anlamlılık düzeyini kaybetmemiştir ( $c^{\prime}$ yolu; $\beta=.30, S H=.07, t=4.62, p<.01$, CI $[.17, .43]$ ). Bu bulgular, travma puanı yüksek grupta, travmatik stres düzeyi ve travma sonrası büyüme arasındaki ilişkide algılanan sosyal destek ve manevi yönelimin aracılık ettiği bazı dolaylı etkilerin anlamlı olabileceğine işaret etmektedir.

İlk dolaylı etki (ind1), travmatik stres düzeyinin algılanan sosyal destek aracılığıyla travma sonrası büyüme üzerindeki dolaylı etkisidir (travmatik stres düzeyi $\rightarrow$ algılanan sosyal destek $\rightarrow$ travma sonrası büyüme), $a_{1} b_{1}=(0.16)(0.41)=0.06$. Bu dolaylı etki istatistiksel olarak anlamlı düzeyde pozitiftir çünkü bootstrap güven aralığı sıfırın üzerindedir (CI $[.01, .13])$. Bu bulgular, travmatik stres düzeyi arttıkça algılanan sosyal desteğin arttığını ( $a_{1}$ pozitif) ve alg1lanan sosyal desteğin artmasının da travma sonrası büyümenin artması ile -manevi yönelimden bağımsız olarak- ilişkili olduğunu göstermektedir ( $b_{1}$ pozitif).

İkinci dolaylı etki (ind2), travmatik stres düzeyinin, algılanan sosyal destek ve manevi yönelim aracılığıyla travma sonrası büyüme üzerindeki seri etkisidir (travmatik stres düzeyi $\rightarrow$ algılanan sosyal destek $\rightarrow$ manevi yönelim $\rightarrow$ travma sonrası büyüme), $\mathrm{a}_{1} \mathrm{~d}_{1} \mathrm{~b}_{2}=(0.16)(0.63)(0.16)=0.02$. Bu dolaylı etki anlamlı düzeyde pozitiftir çünkü bootstrap güven aralığı sıfirın üzerindedir (CI $[.00, .04]$ ). Bu bulgular, travmatik stres düzeyi yüksek olan kişilerin sosyal çevreden daha fazla destek algıladığını ( $a_{1}$ pozitif); algılanan sosyal destek arttıkça kişilerin manevi yöneliminin arttığını ( $\mathrm{d}_{1}$ pozitif); buna bağlı olarak da travma sonrası büyümenin arttığını göstermektedir ( $b_{2}$ pozitif).

Üçüncü dolaylı etki (ind3), travmatik stres düzeyinin manevi yönelim aracılığıyla travma sonrası büyüme üzerindeki dolaylı etkisidir (travmatik stres düzeyi $\rightarrow$ manevi yönelim $\rightarrow$ travma sonrası büyüme), $\mathrm{a}_{2} \mathrm{~b}_{2}=(-0.05)(0.16)=-0.01$. Ancak bu dolaylı etki istatistiksel olarak anlamlı değildir çünkü bootstrap güven aralığı sıfır değerini içermektedir (CI [-.04, .02]). Yanı sıra, tüm modelin anlamlı olduğu $\left(F(3,342)=53.71, p^{\left.<.001, R^{2}=.32\right)}\right.$ ve toplam varyansin \%32'sini açıkladığı görülmüştür.

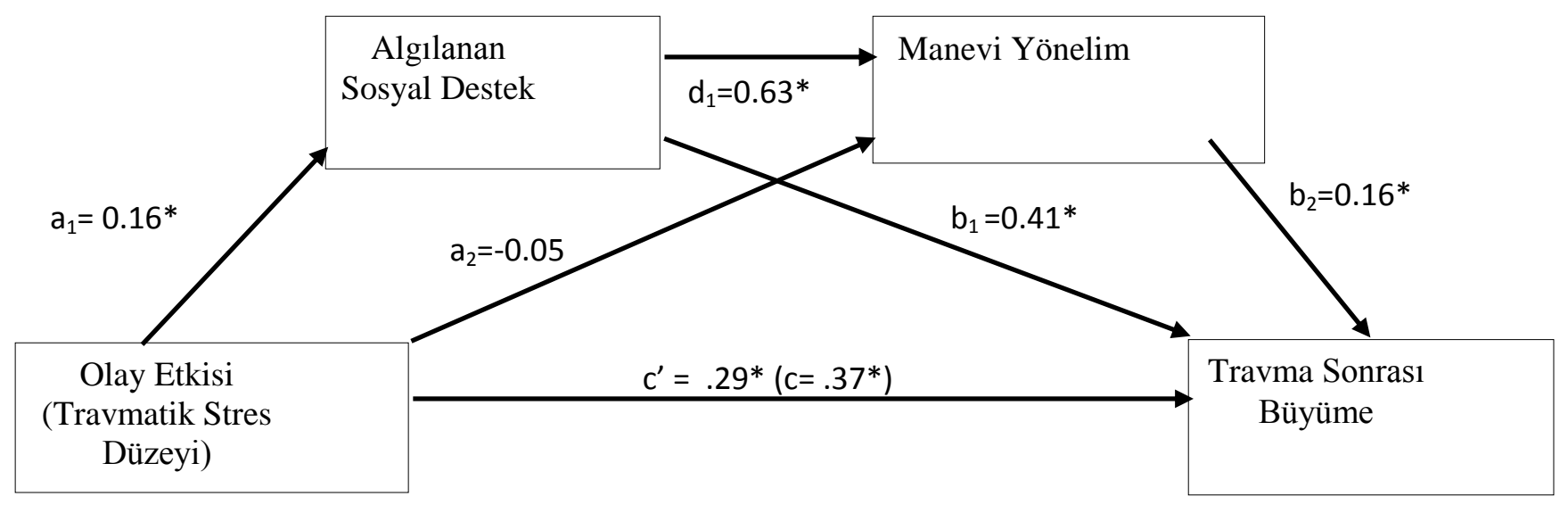

Şekil 2. Travma Puanı Yüksek Grupta Seri Çoklu Aracılık Modeli 
Tablo 2. Travma Puanı Yüksek Grupta Seri Çoklu Aracı Değişken Analizi

\begin{tabular}{|c|c|c|c|c|c|c|c|c|c|c|}
\hline \multirow[b]{3}{*}{ Değişken } & \multicolumn{10}{|c|}{ Sonuç } \\
\hline & \multicolumn{3}{|c|}{$A_{l}(A S D)$} & \multicolumn{4}{|c|}{$A_{2}(M Y)$} & \multicolumn{3}{|c|}{$Y(T S B)$} \\
\hline & Coeff $(\overline{\beta)}$ & SH & $p$ & & Coeff $(\bar{\beta})$ & SH & $p$ & & Coeff $(\bar{\beta}) \quad S H$ & $p$ \\
\hline $\mathrm{X}(\mathrm{TS})$ & $\mathbf{a}_{1} \quad 0.16$ & .07 & .02 & $\mathbf{a}_{2}$ & -.05 & .09 & .59 & c' & .29 & .00 \\
\hline $\mathrm{A}_{1}(\mathrm{ASD})$ & ---- & ----- & ---- & $d_{1}$ & .63 & .06 & .000 & $\mathbf{b}_{1}$ & .41 & .000 \\
\hline $\mathrm{A}_{2}(\mathrm{MY})$ & ----- & ------ & ---- & & ---- & ----- & ----- & $\mathbf{b}_{2}$ & .16 & .000 \\
\hline \multirow[t]{3}{*}{ Sabit } & 51.77 & 3.66 & .000 & & 51.66 & 5.37 & .000 & & 15.14 & .001 \\
\hline & \multicolumn{3}{|c|}{$R^{2}=.02$} & \multicolumn{4}{|c|}{$R^{2}=.23$} & \multicolumn{3}{|c|}{$R^{2}=.32$} \\
\hline & \multicolumn{3}{|c|}{$F(1,346)=5.44, p=.02$} & \multicolumn{4}{|c|}{$F(2,345)=49.99, p=.000$} & \multicolumn{3}{|c|}{$F(3,344)=54.43, p=.000$} \\
\hline
\end{tabular}

$\mathrm{A}=$ Aracı Değişken, TS= Travmatik Stres, ASD= Algılanan Sosyal Destek, MY= Manevi Yönelim, $\mathrm{TSB}=$ Travma Sonrası Büyüme

\section{Travma Puanı Düşük Grupta Seri Aracı Değişken Analizi}

Travmatik stres düzeyi düşük olan grupta yapılan seri çoklu aracı değişken analizine göre, bu grupta travmatik stres düzeyinin travma sonrası büyüme üzerindeki toplam etkisi anlamlıdır ( $c$ yolu; $\beta=.29, S H=.07, t=4.52, p<.01$, CI [.17, .42]). Aracı değişkenler (algılanan sosyal destek ve manevi yönelim) denkleme eş zamanlı alındığında travmatik stres düzeyi ile travma sonrası büyüme arasındaki doğrudan ilişki artmış ve anlamlılık düzeyini kaybetmemiştir ( $c^{\prime}$ yolu; $\beta=.35, S H=.06, t=5.69, p<.01$, CI [.23, .46]). Bu bulgular, travma puanı düşük grupta, travmatik stres düzeyi ve travma sonrası büyüme arasındaki ilişkide algılanan sosyal destek ve manevi yönelimin seri aracı rolünün bulunmadığına işaret etmektedir.

Tablo 3. Travma Puanı Düşük Grupta Seri Çoklu Aracı Değişken Analizi

\section{Sonuç}

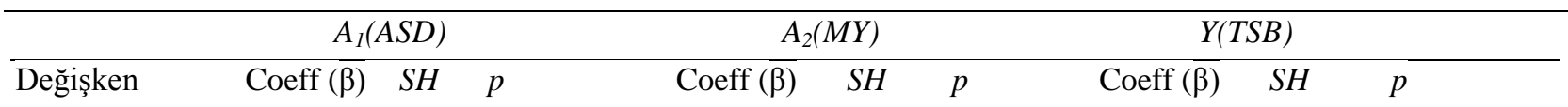

\begin{tabular}{|c|c|c|c|c|c|c|c|c|c|c|}
\hline $\mathrm{X}(\mathrm{TS})$ & $\mathbf{a}_{1}$ & -.05 & .37 & $\mathbf{a}_{2}$ & -.17 & .01 & c' & .35 & .06 & .000 \\
\hline $\mathrm{A}_{1}(\mathrm{ASD})$ & & ----- & --- & $d_{1}$ & .37 & .000 & $\mathbf{b}_{1}$ & .29 & .06 & .000 \\
\hline $\mathrm{A}_{2}(\mathrm{MY})$ & & ------ & --- & & ---- $\quad$----- & ---- & $\mathbf{b}_{2}$ & .21 & .05 & .000 \\
\hline Sabit & & $61.75 \quad 2.09$ & .000 & & $72.38 \quad 4.52$ & .000 & & 15.15 & 5.31 & .01 \\
\hline & & \multicolumn{2}{|c|}{$R^{2}=.00$} & \multicolumn{3}{|c|}{$R^{2}=.10$} & \multicolumn{4}{|c|}{$R^{2}=.19$} \\
\hline & \multicolumn{3}{|c|}{$F(1,375)=.80, p=.37$} & \multicolumn{3}{|c|}{$F(2,374)=21.77, p=.000$} & \multicolumn{4}{|c|}{$F(3,373)=28.90, p=.000$} \\
\hline
\end{tabular}

$\mathrm{A}=$ Aracı Değişken, TS= Travmatik Stres, ASD= Algılanan Sosyal Destek, MY= Manevi Yönelim, $\mathrm{TSB}=$ Travma Sonrası Büyüme

\section{TARTIŞMA VE SONUÇ}

$\mathrm{Bu}$ çalışmanın amacı, terör olayları karşısında yetişkin bireylerde görülen travma sonrası stres belirtileri ile travma sonrası büyüme arasındaki ilişkide algılanan sosyal desteğin ve 
maneviyatın aracı rolünü incelemektir. Literatürdeki birçok çalışmada (Bleich ve ark. 2003; Butler ve ark. 2005; Dekel ve Hobfoll 2007; Helgeson ve ark. 2006; Laufer ve Solomon 2006) travma sonrası büyümenin orta ve yüksek düzeyde travma sonrası stres belirtileri gösteren bireylerde görüldüğü ifade edildiğinden, bu çalışmada travma sonrası stres belirtileri ile travma sonrası büyüme arasındaki ilişkide algılanan sosyal desteğin ve maneviyatın aracı rolü travma sonrası stres düzeyi iki gruba ayrılarak (travma sonrası stres düzeyi yüksek olan ve travma sonrası stres düzeyi düşük olan grup) incelenmiştir.

Mevcut çalışmanın ilk sonucu travmatik stres düzeyinin yüksek olduğu grupta travma sonrası büyüme üzerindeki toplam etki anlamlı çıkmıştır. Bu sonuç, alanyazında, travma sonrası büyümenin olabilmesi için bireyin zorlu yaşam deneyiminden geçmesi ve bu yaşam deneyiminden etkilenmesi gerektiğine yönelik bulgular ile paralellik göstermektedir (Bleich ve ark. 2003; Butler ve ark. 2005; Tedeschi ve Calhoun 2004). Janoff-Bulman (1992), travma sonrası büyümenin olabilmesi için bireyin zorlu yaşam deneyimini yaşaması, bu zorlu deneyimden etkilenmesi; öte yandan bireyin yaşama dair üç temel varsayımının (dünyanın hayırseverliği, dünyanın anlamlılığı ve kişinin kendine verdiği değer) sarsılmaması gerektiğini ifade etmiştir. Buradan hareketle, bireyin travma yaşarken üç temel varsayımının sarsılmaması ve travma sonrası büyüme yaşamasında aracı başka etmenlerin olduğu düşünülebilir.

$\mathrm{Bu}$ çalışmanın ikinci sonucu travmatik stres düzeyi arttıkça algılanan sosyal desteğin arttığıdır. Bu sonuç alan yazınında sosyal desteğin travma sonrası stres ile ilişkili olduğunu gösteren bir çok çalışmanın (Calhoun ve ark. 2010; Calhoun ve Tedeschi 2006) bulgusu ile de paralellik göstermektedir. Calhoun ve arkadaşları (2010) sosyal desteğin bireyin çevresinden algıladığı olumlu bir tepki olduğundan bireyin travma ile başa çıkmasını olumlu yönde etkilediğini ve hatta bireyin travma sonrası büyüme yaşamasına yol açtığını vurgulamıştır. Ayrıca sosyal desteğin; bireyin yalnızlık hissini aldığını ve travma sonrası büyümede önemli bir rolü olduğunu ifade eden birçok çalışma da (Cryder ve ark. 2006; Maguen ve ark. 2006; Prati ve Pietrantoni 2009; Tedeschi ve Calhoun 2004) alanyazında mevcuttur. Sosyal destek, zorlayıcı olay hakkında bireye geri bildirim sağlayabildiğinden bunun bir tür bilişsel destek olduğunu öne süren çalışmalar da (Cryder ve ark. 2006; Tedeschi ve Calhoun 2004) bulunmaktadır. Kısacası bu çalışmalarda travmatik stres düzeyi arttıkça algılanan sosyal desteğin arttığı ve algılanan sosyal destek artıkça da travma sonrası büyüme arttığı vurgulamaktadır. Bütün bu çalışmalar, araştırmanın üçüncü sonucu olan sosyal destek ile travma sonrası büyüme arasındaki ilişkiyi ve araştırmanın bir diğer sonucu olan travma sonrası stres ile travma sonrası büyüme arasındaki ilişkide sosyal desteğin aracı rolünü destekler niteliktedir.

Araştırmanın bir diğer bulgusu da travma sonrası stres düzeyi yüksek olan grupta travma sonrası stres düzeyi ile manevi yönelim arasında anlamlı bir ilişki bulunmamamasındır. Literatürde maneviyatın bireyin travmasını olumlu (Ano ve Vasconcelles, 2005; MoreiraAlmeida ve Koenig, 2006) veya olumsuz (Pargament, Koenig, Tarakeshwar, \& Hahn, 2001) etkilediğini gösteren klinik grupta yapılan çalışmalar bulunmaktadır. Bu çalışmanın bulgusu literatürü desteklememektedir. Bu bulgunun literatürü desteklememesinde bu çalışmanın klinik olmayan grupta yapılmış olması olabilir. Ancak çalışmanın bir diğer bulgusu olan travma sonrası stres düzeyi yüksek olan grupta manevi yönelimle travma sonrası büyüme arasında anlamlı bir ilişki bulunmuştur. Alan yazınında maneviyat ile travma sonrası büyüme arasında ilişki olduğunu gösteren bir çok çalışma (Linley 2003; Pargament ve ark. 2000; Tedeschi ve Calhoun 1995; Woodcock 2001) araştırmanın bu bulgusunu destekler niteliktedir. Calhoun ve arkadaşları (2010) maneviyat ve travma sonrası büyüme arasındaki ilişkiyi bireylerin travmatik yaşantıdan sonra yaşam felsefesindeki bazı değişikliklerin olması (maneviyat, yaşamdaki önceliklerin belirlenmesi, yaşamın biricikliği) ile açıklamıştır.

Bireyin travmadan sonra yaşam felsefesindeki değişikliklerden maneviyata yönelmesi için sosyal destek gerekebilir. Sosyal destek olmadan, bireyin yalnızlık duygusu ile maneviya- 
ta yönelmesi zor olabilir. Başka bir ifade ile sosyal destekleyici çevre, bireye hem duygusal destek hem de bilişsel destek (zorlayıcı olay hakkında geri bildirim alma) sağlayabildiğinden (Cryder ve ark. 2006, Tedeschi ve Calhoun 2004), bireyi ortama bağlamayı ve bireyin doğa üstü güçlere inanması ve güvenmesini arttırabilir. Bütün bu bulgular ve yorumlar bu araştırmanın sonucu olan travmatik stres ile travma sonrası büyümede manevi yönelimin tek başına aracılığı olmadığı ancak travma sonrası stres ile travma sonrası büyüme arasındaki ilişkide sosyal destekle beraber manevi yönelimin anlamlı olduğunu destekler niteliktedir. Bu bağlamda bu çalışma sosyal desteğin maneviyattan daha önemli olduğunu ve sosyal destek sağlandığında maneviyatın da sosyal destek kadar travma sonrası büyümede etkili olduğunu gözler önüne sermektedir.

Ayrıca, travma sonrası stres düzeyi düşük grupta, travmatik stres düzeyi ve travma sonrası büyüme arasındaki ilişkide algılanan sosyal destek ve manevi yönelimin seri aracı rolünün bulunmadığı ortaya çıkmıştır. Bu bulgu, alanyazında travma sonrası büyümenin gerçekleşebilmesi için travma sonrası stres düzeyinin orta veya yüksek olması gerektiğini ifade eden çalışmaların sonuçları ile paralellik göstermektedir (Bleich ve ark. 2003; Butler ve ark. 2005; Dekel ve Hobfoll 2007; Helgeson ve ark. 2006; Laufer ve Solomon 2006).

$\mathrm{Bu}$ araştırmanın sonuçları göz önünde bulundurulduğunda, çalışmanın çeşitli sınırlılıkları olduğu söylenebilir. Bu sınırlılıklar çerçevesinde gelecek araştırmalar için birtakım öneriler sunulabilir. $\mathrm{Bu}$ araştırmanın bulguları kendini bildirime dayalı ölçeklerden elde edilmiş sonuçlarla sınırlıdır. Kendini bildirime dayalı değerlendirmelerde bireylerin savunucu olma ve kendilerini iyi sunma eğiliminde olmasından dolayı sorulara verilen cevaplarda yanlılıklar olabileceği düşünülmektedir. Ancak bütün bu sınırlılıklara rağmen bu araştırma, dünyada giderek artan savaş ve terör olayları sonucunda yaşanan travma sorunuyla başa çıkmada etken olan sosyal desteğin ve maneviyatın önemini göstererek travma ve travma sonrası büyüme literatürüne katkı sağlamış olabilir. İkinci olarak, bu çalışmadaki bağımlı ve bağımsız değişken için olan veriler tek bir kaynaktan toplanmıştır. Podsakoff ve arkadaşlarına (2003) ve Antonakis ve arkadaşlarına (2010) göre bağımlı ve bağımsız değişkenlere ait verilerin aynı kaynaktan (sadece kişiden) toplanması varyans sapma hatasını ortaya çıkarabilir. Varyans sapma hatasının olumsuz etkilerini azaltmak için çalışmadaki tüm ölçümlerin ayırt ediciliği test edilmiştir. Buna ek olarak, kesitsel tasarımın doğası gereği bu çalışmanın sonuçlarından bir nedensellik iddia edilemez. Bu nedenle gelecekteki araştırmalar nedenselliği kanıtlamak için boylamsal olarak ele alınabilir. Son olarak bu çalışma, travma sonrası stres düzeyi yüksek olan ancak tanı almayan normal popülasyondan elde edilen verilerle sınırlıdır. Bu bağlamda, bu bulgular travma sonrası stres düzeyi yüksek olan ve tanı alan klinik grupta da test edilebilir.

\section{KAYNAKÇA}

Aker, T., Sorgun, E., Mestçioğlu, Ö., Karakaya, I., Kalender, D., Acar, G., Biçer, U. \& Acicbe, O. (2008) İstanbul'daki bombalama eylemlerinin erişkin ve ergenlerdeki travmatik stres etkileri. Türk Psikoloji Dergisi, 23(61), 63-71.

Ano, G. G., \& Vasconcelles, E. B. (2005). Religious coping and psychological adjustment to stress: A meta-analysis. Journal of Clinical Psychology, 61(4), 461-480.

Antonakis, J., Bendahan, S., Jacquart, P., \& Lalive, R. (2010). On making causal claims: A review and recommendations. The Leadership Quarterly, 21(6), 1086-1120

Benight, C.C., Freyaldenhoven, R., Hughes, J., Ruiz, J., Zoschke, T., \& Lovallo, W. (2000). Coping self-efficacy and psychological distress following the Oklahoma City bombing. Journal of Applied Social Psychology, 30, 1331-1344. 
Bleich, A., Gelkopf, M. \& Solomon, Z. (2003). Exposure to terrorism, stress-related mental health symptoms, and coping behaviors among a nationally representative sample in Israel. JAMA 290(5), 612-20.

Burgoon, B.(2006) On welfare and terror. Journal of Conflict Resolution, 50(2), 176-203

Butler, L.D., Blasey, C.M., Azarow, J., McCaslin, S.E., Garlan, R.W., Chen, X.-H.,

Desjardins, J.C., DiMiceli, S., Seagraves, D.A., Hastings, T.A., Kraemer, H.C., \& Spiegel, D. (2005). Posttraumatic growth following the terrorist attacks of September 11, 2001: Cognitive, coping, and trauma symptom predictors in an internet conve ience sample. Traumatology, 11 (4), 247-267

Calhoun, L.G., Cann, A., Tedeschi, R.G. \& McMillan, J. (2000). A correlation test of the relationship between posttraumatic growth, religion, and cognitive processing. Jounal of Traumatic Stress, 13, 521-527.

Calhoun, L.G., Cann, A. \& Tedeschi, R.G. (2010). The post-traumatic growth model:

Sociocultural considerations. In T. Weiss \& R. Berger (Eds.), Posttraumatic growth and culturally competent practice: Lessons learned from around the globe (pp. 1-14). Hoboken, NJ, US: John Wiley \& Sons Inc.

Calhoun, L.G., Tedeschi, R.G. (2006). The foundations of posttraumatic growth: An expanded framework. In Calhoun LG \& Tedeschi RG (Eds.), Handbook of post-traumatic growth: Research and practice (pp. 3-23). Mahwah NJ: Erlbaum.

Cryder, C., Kilmer, R., Tedeschi, R., \& Calhoun, L.(2006). An exploratory study of posttraumatic growth in children following a natural disaster. American Journal of Orthopsychiatry, 76, 65-69.

Çorapçioğlu, A., Yargıç, İ., Geyran, P. \& Koçabaşoğlu, N. (2006). Olayların Etkisi Ölçeği (IES-R)Türkçe versiyonunun geçerlilik ve güvenilirliği. New/Yeni Symposium: Psikiyatri, Nöroloji ve Davranış Bilimleri Dergisi, 44(1),14-22.

Dedeoğlu, B. (2003) Bermuda triangle: Comparing official definitions of terrorist activity. Terrorism and Political Violence, 15, 81-110.

Dekel, R. \& Hobfoll, S.E (2007). The impact of resource loss on Holocaust survivors facing war and terrorism in Israel. Aging Mental Health, 11(2),159-67.

Duran, S. \& Ünsal, G. (2014). Çankırı ilindeki şehit aileleri ve malul gazilerin psikolojik dayanıklılık ve depresif durumlarının belirlenmesi. Acıbadem Üniversitesi Săglık Bilimleri Dergisi, 5(2), 158- 163.

Dürü, C. (2006) Travma sonrası stres belirtileri ve travma sonrası büyümenin çeşitli değişkenler açısından incelenmesi ve bir model önerisi. Yayınlanmamış Doktora Tezi, Hacettepe Üniversitesi

Eker, D., Arkar, H. \& Yaldız, H. (2001) Çok boyutlu algılanan sosyal destek ölçeği’nin gözden geçirilmiş formunun faktör yapısı, geçerlik ve güvenirliği. Türk Psikiyatri Dergisi 12(1):17-25.

Eşsizoğlu, A., Yaşan, A., Bülbül, İ. Önal, S. Akgün-Yıldırım, E. ve Aker, T. (2009). Bir terörist saldırı sonrasında travma sonrası stres bozukluğu gelişimini etkileyen risk faktörleri. Türk Psikiyatri Dergisi 20(2),118-126. 
Everly, G.S. \& Mitchell, J.T. (2001). America under attack: The "10 commandments" of responding to mass terrorist attack. International Journal of Emergency Mental Health 3, 133-135.

Frey, B. S., Luechinger, S., \& Stutzer, A. (2007). Calculating tragedy: assessing the costs of terrorism, Journal Of Economic Surveys, 21(1), 1-24

Galea, S., Ahern, J., Resnick, H., Kilpatrick, D., Buccavalas, M., Gold, J., \& Vlahov, D. (2002). Psychological sequelae of the September 11 terrorist attacks in New York City. New England Journal of Medicine, 346, 982-987.

Galea, S. \& Resnick, H. (2005). Posttraumatic stress disorder in the general population after mass terrorist incidents: Considerations about the nature of exposure. CNS Spectrums $10,107-115$.

Georges, B. (2000). Nietzsche Üzerine. Kabalc1 Yayınevi, İstanbul

Gökler, I. ve Yılmaz, B. (2001). Travmatik savaş yaşantıları ve bunların çocuklar üzerindeki etkileri. Türk Psikoloji Bülteni, 22, 89-99.

Güloğlu, B. \& Irmak, O. (2013). Güneydoğu gazilerinde travma sonrası stres bozukluğu gelişimi. Anadolu Psikiyatri Dergisi 14, 237-44.

Hall, B.J., Hobfoll, S.E, Palmieri, P.A., Canetti-Nisim, D., Shapira, O., Johnson, R. J., Galea, S. (2008). The psychological impact of impending forced settler disengagement in Gaza: trauma and posttraumatic growth. Journal of Traumatic Stress, 21(1): 22-29.

Hayes, A.F. (2009). Beyond Baron and Kenny: Statistical mediation analysis in the new millenium. Communication Monographs, 76(4),408-420.

Hayes, A. F. (2013). Introduction to mediation, moderation, and conditional process anal sis: A regression-based approach. New York, NY: Guilford.

Helgeson, V.S., Reynolds, K.A. \& Tomich, P.L. (2006). A meta-analytic review of benefit finding and growth. Special Issue: Benefit-Finding 74(5), 797-816.

Hobfoll, S.E., Canetti, N.D. \& Johnson, R.J. (2006) Exposure to terrorism, stress-related mental health symptoms, and defensive coping among Jews and Arabs in Israel. Journal of Consulting and Clinical Psychology, 74(2),207-218.

Hobfoll, S. E., Canetti-Nisim, D., Johnson, R. J., Palmieri, P. A., Varley, J. D., \& Galea, S.(2008). The association of exposure, risk, and resiliency factors with PTSD among Jews and Arabs exposed to repeated acts of terrorism in Israel. Journal of Traumatic Stress, 21, 9-21.

Horowitz, M., Wilner, N. \& Alvarez, W. (1979) Impact of Event Scale: A measure of stress. Psychosomatic Medicine, 41, 209-218.

Ironson, G., Wynings, C., Schneiderman, N., Baum, A.,Rodriguez, M., Greenwood, D., et al. (1997). Posttraumaticstress symptoms, intrusive thoughts, loss, and immune function after Hurricane Andrew. Psychosomatic Medicine, 59, 128-141

Janoff-Bulman, R. (1992). Shattered assumptions: Towards a new psychology of trauma. New York NY US:Free Press. 
Janoff-Bulman, R. (2006). Schema-change perspectives on posttraumatic growth. In Calhoun

LG \& Tedeschi RG (Eds.), Handbook of posttraumatic growth: Research \& practice (pp. 81-99). Mahwah NJ US Lawrence Erlbaum Associates Publishers.

Kardaş, F. \& Tanhan, F. (2018). Van depremini yaşayan üniversite öğrencilerinin travma sonrası stres, travma sonrası büyüme ve umutsuzluk düzeylerinin incelenmesi. Yüzüncü Yll Üniversitesi Ĕ̈itim Fakültesi Dergisi, 15(1):1-36.

Karaman, Ö. \& Tarım, B. (2018). Travma sonrası büyüme, sosyal problem çözme ve iyimserlik arasındaki ilişkilerin incelenmesi. Dicle Üniversitesi Sosyal Bilimler Enstitüsü Dergisi, 20,190-198.

Karasar, N. (2012). Bilimsel araştırma yöntemleri. Ankara: Nobel Yayın Dağıtım.

Kasapoğlu, F. (2015). Manevi yönelim ölçeği’nin geliştirilmesi: Geçerlik ve güvenirlik çalışması. İnönü Üniversitesi Ĕgitim Fakültesi Dergisi, 16(3),51-68.

Laufer, A. \& Solomon, Z. (2006). Posttraumatic symptoms and posttraumatic growth among Israeli youth exposed to terror incidents. Journal of Social and Clinical Psychology, 25(4):429-448.

Linley, P. A. (2003). Positive adaptation to trauma: wisdom as both process and outcome. Journal of Trauma Stress, 16(6),601-10.

Maguen, S., Vogt, D. S., King, L. A., King, D. W., \& Litz, B. T. (2006). Posttraumatic growth among Gulf War I veterans: The predictive role of deployment-related

experiences and background characteristics. Journal of Loss and Trauma, 11, 373 388.

Moreira-Almeida, A., \& Koenig, H. G. (2006). Retaining the meaning of the words religiousness and spirituality. Social Science \& Medicine, 63(4), 840-845.

Milam, J., Ritt-Olson, A., Tan, S., Unger J., \& Nezami, E. (2005). The September 11th 2001 terrorist attacks and reports of posttraumatic growth among a multi-ethnic sample of adolescents. Traumatology, 11, 233-246.

Norris, F., Friedman, M. \& Watson, P. (2002). 60,000 Disaster victims speak: Part II, summary and implications of the disaster mental health research. Psychiatry, 65, 240-260.

Pargament K.I., Koenig H.G. \& Perez L.M. (2000) The many methods of religious coping: development and initial validation of the RCOPE. Journal of Clinical Psychology 56,(4), 519-543.

Pargament, K. I., Koenig, H. G., Tarakeshwar, N., \& Hahn, J. (2001). Religious struggle as a predictor of mortality among medically ill elderly patients: A 2-year longitudinal study. Archives of Internal Medicine, 161(15), 1881-1885.

Podsakoff, P. M., MacKenzie, S. B., Lee, J. Y., \& Podsakoff, N. P. (2003). Common method biases in behavioral research: A critical review of the literature and recommended remedies. Journal of Applied Psychology, 88(5), 879.

Prati, G. \& Pietrantoni, L. (2009). Optimism, social support, and coping strategies as factors contributing to posttraumatic growth: A Meta-Analysis. Journal of Loss and Trauma, 14(5),364-388. 
Rime', B. (2009). Emotion elicits the social sharing of emotion: Theory and empirical review. Emotion Review, 1, 60-85.

Shalev, A.Y., Tuval, R., Frenkiel-Fishman, S., Hadar, H., \& Eth, S. (2006). Psychological responses to continuous terror: A study of two communities in Israel. American Journal of Psychiatry, 163, 667-673.

Shaw, A., Joseph, S. \& Linley, P.A (2005). Religion, spirituality, and posttraumatic growth: a systematic review. Mental Health, Religion \& Culture, 8(1),1-11.

Şavur, E. \& Tomas, S.A. (2010). Terör olayları sonrasında psikososyal destek hizmetleri. Kriz Dergisi, 18 (1): 45-58.

Tabachnick, B. G. \& Fidell, L. S. (2006). Using multivariate statistics (5th ed.). Boston: A lyn and Bacon.

Tedeschi, R.G. \& Calhoun, L.G. (1995) Trauma and transformation: Growing in the after math of suffering. Thousand Oaks CA:Sage

Tedeschi, R.G. \& Calhoun, L.G. (1996) The posttraumatic growth inventory: Measuring the positive legacy of trauma. Journal of Traumatic Stress, 9, 455-471.

Tedeschi, R.G. \& Calhoun, L.G. (2004). Target Article: "Posttraumatic growth: Conceptual foundations and empirical evidence". Psychological Inquiry 15(1):1-18.

Weiss, D.S. \& Marmar, C.R. (1997). The impact of Event Scale - Revised. In J. P. Wilson, T M. Keane, editors. Assessing psychological trauma and PTSD. (pp.399-411).New York: Guilford.

Woodcock, J. (2001). Trauma and spirituality. In Trauma: A practitioner's guide to counseling, T. Spiers (Ed.), pp. 131-156. New York: Brunner-Routledge.

Zimet, G.D. Dahlem, N.W., Zimet, S.G. Farley, G.K (1988) The Multidimensional Scale of Perceived Social Support. Journal of Personality of Assessment, 52, 30-41.

Zoellner, T. \& Maercker, A. (2006). Posttraumatic growth in clinical psychology-A critical review and introduction of a two-component model. Clinical Psychology Review, 26, $626-653$. 